\section{A Petiole Sap Nitrate Test for Cauliflower}

\author{
Aki Kubota, Thomas L. Thompson ${ }^{1}$, Thomas A. Doerge, and \\ Ronald E. Godin \\ Department of Soil, Water, and Environmental Science, University of Arizona, \\ 429 Shantz, Building \#38, Tucson, AZ 85721
}

Additional index words. tissue testing, crop N status, Brassica oleracea

\begin{abstract}
This study was conducted to evaluate the accuracy of sap analysis using a portable nitrate ion meter for cauliflower (Brassica oleracea L. Botrytis Group, cv. Candid Charm) petiole nitrate determination. The relationship between $\mathrm{NO}_{3}-\mathrm{N}$ concentration in fresh petiole sap and in dried petiole tissue was studied for cauliflower grown in southern Arizona during the 1993-94 and 1994-95 growing seasons. Experiments were factorial combinations of three water rates and four $\mathrm{N}$ rates, both ranging from deficient to excessive. Petioles were collected throughout each season and were split for analysis of sap $\mathrm{NO}_{3}$-N and dried petiole $\mathrm{NO}_{3}$-N. Linear correlations between the two methods were similar in both seasons, with no consistent effect due to water application rate or crop maturity. Therefore, a single regression equation was derived: petiole $\operatorname{sap~} \mathrm{NO}_{3}-\mathrm{N}\left(\mathrm{mg}^{-l i t e r}{ }^{-1}\right)=0.047$ $\times$ dry petiole $\mathrm{NO}_{3}-\mathrm{N}\left(\mathrm{mg} \cdot \mathrm{kg}^{-1}\right)+218\left(\mathrm{r}^{2}=0.772\right)$. This equation can be used to relate sap test measurements to existing guidelines for $\mathrm{NO}_{3}-\mathrm{N}$ concentrations in cauliflower petioles. These results suggest that the quick sap test, using the portable nitrate ion meter, is a valuable technique for monitoring $\mathbf{N}$ status of cauliflower.
\end{abstract}

Plant tissue analysis offers growers a measure of crop nutrient status for guiding applications of nutrients during the growing season. Plant tissue analysis can be an especially valuable tool for following agricultural Best Management Practices in irrigated cropping systems where each irrigation event represents an opportunity to apply required nutrients efficiently (Doerge et al., 1991).

The youngest fully matured leaf is an actively growing plant part and is an excellent choice for nutrient analysis with many crops (Geraldson et al., 1973). Leaf petiole plus midrib $\mathrm{NO}_{3}-\mathrm{N}$ concentration has proven to be a reliable guide for determining the $\mathrm{N}$ status of cauliflower(Welch et al., 1985). Lorenz (1965) observed that $5000 \mathrm{mg} \mathrm{NO}-\mathrm{N} / \mathrm{kg}$ was deficient for cauliflower at the buttoning stage. Critical $\mathrm{NO}_{3}-\mathrm{N}$ levels in cauliflower petioles and guidelines for interpretation during the entire growing season have also been established for desert growing conditions (Doerge et al., 1991; Gardner and Roth, 1990). However, testing dry tissue samples by conventional laboratory methods may present a limitation to growers because of the 2- to 3-day delay between the time of sampling and return of results.

Quick petiole sap tests using nitrate test strips have been compared with conventional dry tissue analysis for potato (Solanum tuberosum L.) (Williams and Maier, 1990), cereals (Papastylianou, 1989), cabbage (Bras-

Received for publication 20 Feb. 1996. Accepted for publication 9 May 1996. The cost of publishing this paper was defrayed in part by the payment of page charges. Under postal regulations, this paper therefore must be hereby marked advertisement solely to indicate this fact.

${ }^{1}$ To whom reprint requests should be addressed. sica oleracea L. Capitata Group) (Scaife and Stevens, 1983), and other vegetable crops (Prasad and Spiers, 1984). A recently developed portable nitrate-selective electrode that can directly measure $\mathrm{NO}_{3}-\mathrm{N}$ in fresh petiole sap may have potential for near real-time measurements. Westcott et al. (1993) obtained a coefficient of determination $\left(\mathrm{r}^{2}\right)$ of 0.925 for the relationship between the sap test and dry tissue analysis for potato. They suggested using a regression equation to convert sap test results to dry tissue $\mathrm{NO}_{3}-\mathrm{N}$ concentrations. Hodges and Baker (1993) evaluated the sap test for cotton (Gossypium hirsutum L.) and observed that it was highly correlated with dry tissue analysis only at the early growth stages. Hartz et al. (1994) compared petiole sap $\mathrm{NO}_{3}-\mathrm{N}$ using a portable electrode with dry tissue analysis for broccoli (Brassica oleracea L. Italica Group), celery (Apium graveolens L.), corn (Zea mays L.), lettuce (Lactuca sativa L.), pepper (Capsicum annuum L.), tomato (Lycopersicon esculentum Mill.), and watermelon [Citrullus lanatus (Thunb.)] and obtained $\mathrm{r}^{2}$ values of between 0.65 and 0.89 . Diagnostic criteria for $\mathrm{NO}_{3}-\mathrm{N}$ in stem sap, using the portable nitrate meter, have been defined for tomato seedlings (Beverly, 1994). Hartz et al. (1993) observed that the relationship for pepper was not significantly influenced by cultivar, site, or maturity. They concluded that the sap test with the portable electrode meter was less subjective and more highly correlated with the standard laboratory method for dry tissue analysis than was the colorimetric test-strip technique. Hochmuth (1992) presented a comprehensive discussion of sampling and procedural factors that are required for using plant sap testing successfully.

The sap $\mathrm{NO}_{3}-\mathrm{N}$ test has not yet been evaluated for cauliflower. The objective of this study was to evaluate the accuracy of the sap test for cauliflower petiole $\mathrm{NO}_{3}-\mathrm{N}$ determination in comparison to a standard method of dry tissue analysis. Additionally, guidelines to interpret plant $\mathrm{N}$ status of cauliflower by the sap test are suggested.

\section{Materials and Methods}

'Candid Charm' cauliflower was grown in irrigation rate $\times \mathrm{N}$ fertilizer rate experiments during the 1993-94 and 1994-95 winter growing seasons at the Univ. of Arizona Maricopa Agricultural Center in southern Arizona. The field used during each year is mapped as a Casa Grande sandy loam [fine-loamy, mixed, hyperthermic, Typic Natrargid (reclaimed)]. The experimental field was cropped with unfertilized, flood-irrigated sudangrass (Sorghum sudanense L.) for about 5 months before planting cauliflower each year to minimize field variability and reduce concentrations of available N. The above-ground biomass of sudangrass was cut and removed from the field three or more times.

In 1993-94, seeds were sown in an expanded foam growth medium in a greenhouse on 17 Aug. 1993. The plants were transplanted at the three- to four-leaf stage in one row per bed on 2 Oct. 1993. The plant population was 30,000 plants/ha. Curd harvest was from 21 Jan. to 1 Feb. 1994. In 1994-95, seeds were sown directly in a single row per bed using a Stanhay precision planter (Stanhay Webb, Exning, Suffolk, England) on 17 Sept., and

Table 1. Schedule of $\mathrm{N}$ fertilizer applications for cauliflower for the 1993-94 and 1994-95 seasons.

\begin{tabular}{lcrrrrrrr}
\hline & & & DAT/ & \multicolumn{5}{c}{ Nitrogen treatment (kg N/ha) } \\
\cline { 5 - 8 } Season & Growth stage & DCD $^{z}$ & DAPy & 1 & 2 & \multicolumn{1}{c}{3} & \multicolumn{1}{c}{4} \\
\hline 1993-94 & 4- to 5-leaf & 89 & 5 & 0 & 55 & 70 & 85 & --- \\
& 6- to 8-leaf & 356 & 24 & 20 & 60 & 60 & 90 & -- \\
& 12-leaf & 548 & 47 & 20 & 80 & 80 & 160 & -- \\
& Buttoning & 672 & 66 & 20 & 105 & 180 & 190 & --- \\
Total & 3- to 4-cm curds & 737 & 82 & 0 & 40 & 60 & 75 & -- \\
1994-95 & & & & 60 & 340 & 450 & 600 & -- \\
& 2-leaf & 384 & 23 & 0 & 20 & 40 & 60 & 67 \\
& 6-leaf & 659 & 49 & 20 & 40 & 60 & 100 & 40 \\
& 8- to 9-leaf & 738 & 63 & 30 & 50 & 80 & 150 & 129 \\
Total & Leaves folding & 866 & 88 & 40 & 60 & 70 & 120 & 56 \\
& Curd development & 998 & 112 & 10 & 30 & 50 & 70 & 0 \\
& & & & 100 & 200 & 300 & 500 & 292 \\
\hline
\end{tabular}

${ }^{\mathrm{z}} \mathrm{DCD}=$ degree $\mathrm{C}$ days refers to accumulated heat units within the range of 7 to 30C (Snyder, 1985).

${ }^{y} \mathrm{DAT}=$ days after transplanting in 1993-94; DAP = days after planting in 1994-95. 
then irrigated on 20 Sept. 1994. Plants were thinned to the final population at the four- to six-leaf stage. Harvest was from 25 Jan. to 3 Feb. 1995.

During each growing season, trickle tubing was buried $0.15 \mathrm{~m}$ deep directly under the midline of raised soil beds spaced $1.02 \mathrm{~m}$ apart. Uniform irrigations were applied to all plots until the stand was established (one- to two-leaf stage) in the 1994-95 season. A tensiometer was installed at a $0.3-\mathrm{m}$ depth in each plot shortly after germination for monitoring soil moisture status. Irrigation was applied daily to maintain target soil water tensions, except when rainfall or cool weather made irrigation unnecessary.

All $\mathrm{N}$ fertilizer was supplied as a solution of urea-ammonium nitrate $(320 \mathrm{~g} \mathrm{~N} / \mathrm{kg})$. The fertilizer was injected directly into the irrigation water using venturi-type chemigators (Performance Products, Coolidge, Ariz.). Five split $\mathrm{N}$ applications in the two experiments were scheduled to occur at $\approx 3$-week intervals (Table $1)$.

The experiments in both seasons were factorial randomized complete block designs with three irrigation rates, four $\mathrm{N}$ application rates, and four replications. Each experimental plot contained four raised beds $12.2 \mathrm{~m}$ long. During each year, $\mathrm{N}$ fertilizer rates (Table 1 ) and target soil water tensions (Table 2) ranged from deficient to excessive. These treatments provided a wide range of petiole $\mathrm{NO}_{3}-\mathrm{N}$ concentrations for comparing the two petiole $\mathrm{NO}_{3}-\mathrm{N}$ analysis methods. During 1994-95, a 13th water $\times \mathrm{N}$ treatment was included. This "best management practices" treatment received the optimum irrigation rate and $\mathrm{N}$ fertilizer application based solely on petiole analysis and preliminary calibrations (Doerge, unpublished data).

Table 2. Target soil water tensions, actual soil water tensions, and amounts of water applied to cauliflower during the 1993-94 and 1994-95 growing seasons.

\begin{tabular}{|c|c|c|c|c|}
\hline \multirow[b]{2}{*}{ Season } & \multirow{2}{*}{$\begin{array}{l}\text { Irrigation } \\
\text { treatment }\end{array}$} & \multicolumn{2}{|c|}{$\begin{array}{c}\text { Soil water } \\
\text { tension }(\mathrm{kPa})\end{array}$} & \multirow{2}{*}{$\begin{array}{l}\text { Water } \\
\text { applied } \\
(\mathrm{mm})^{y}\end{array}$} \\
\hline & & Target & $\overline{\operatorname{Avg}^{2}}$ & \\
\hline \multirow[t]{3}{*}{ 1993-94 } & Deficient & 12.0 & 17.5 & 350 \\
\hline & Optimum & 7.0 & 7.8 & 400 \\
\hline & Excessive & 4.0 & 4.2 & 781 \\
\hline \multirow[t]{3}{*}{ 1994-95 } & Deficient & 20.0 & 12.6 & 167 \\
\hline & Optimum & 12.0 & 9.4 & 199 \\
\hline & Excessive & 4.0 & 4.0 & 573 \\
\hline
\end{tabular}

${ }^{\mathrm{z}}$ Average of soil water tension measured daily be fore irrigation.

${ }^{\mathrm{y}} \mathrm{Sum}$ of precipitation and postestablishment irrigation.
Petiole plus midrib (hereafter designated as petiole) samples were taken from all plots within $2 \mathrm{~h}$ of midday (Scaife and Stevens, 1983) at four growth stages in both years. Petiole samples from the first sampling dates (21 Oct. 1993 and 3 Nov. 1994) were composited across irrigation treatments because the quantity of plant tissue from each plot was too small to obtain sufficient petiole sap. In addition, differences in soil water status between the three irrigation treatments were minimal on these dates. Six to 12 youngest fully matured leaves were sampled randomly from each plot. The petiole tissues were immediately separated from leaf blades, stored in sealed plastic bags, and transported on ice in an insulated cooler from the field to the laboratory. The following day, the petioles in each sample were longitudinally split using a handheld razor blade and separated into two subsamples. One subsample was squeezed in a stainless steel garlic crusher or in a manual arbor press to express sap samples for determining $\mathrm{NO}_{3}-\mathrm{N}$ concentrations. Two to three drops of the expressed sap were placed directly on the sensor pad of a Cardy compact nitrate ion meter (Horiba, Kyoto, Japan). The Cardy meter was calibrated after every 10 measurements using a $\mathrm{KNO}_{3}$ standard in strict accordance with manufacturer's recommendations. The other petiole subsample was weighed fresh, oven-dried at $65 \mathrm{C}$ for $48 \mathrm{~h}$, and then reweighed to permit calculation of moisture content. The dried sample was then ground to pass a $425-\mu \mathrm{m}$ (40 mesh) screen for dry tissue analysis. Dried petiole samples were extracted with $0.025 \mathrm{M} \mathrm{Al}_{2}\left(\mathrm{SO}_{4}\right)_{3}$. Nitrate-N concentrations were determined by a nitrateselective ion electrode (model 93-07; Orion Research, Boston, Mass.) using the procedure of Baker and Thompson (1992).

Regression analysis between the two methods were performed for individual sampling dates and for individual water treatments. Overall regression equations for 1993-94 and 1994-95 were compared by procedures outlined by Snedecor and Cochran (1980).

\section{Results and Discussion}

The marketable yield of cauliflower curds was highly responsive to the rate of applied $\mathrm{N}$ and ranged from $3.5 \mathrm{Mg} \cdot \mathrm{ha}^{-1}$ with deficient $\mathrm{N}$ to $22.3 \mathrm{Mg} \cdot \mathrm{ha}^{-1}$ with excessive $\mathrm{N}$ (detailed data not shown). The 5-year average (198994) of cauliflower yield in Arizona is 13.0 Mg.ha ${ }^{-1}$ (Sherman and Erwin, 1995), indicating high-yielding, but representative, growing conditions in these studies.

Nitrate- $\mathrm{N}$ concentrations of cauliflower petiole sap, as measured by the Cardy meter, were regressed against dried petiole $\mathrm{NO}_{3}-\mathrm{N}$ for individual sampling dates. Each individual regression equation was significant at $P<0.01$ in both years. Slopes and intercepts of the regression equations varied depending on growth stages in 1993-94 but not in 1994-95 (Table 3). The reason for the variation in slope during 1993-94 is unclear. These results do not invalidate the statement by Hartz et al. (1994) that the relationship between petiole sap and dry tissue $\mathrm{NO}_{3}-\mathrm{N}$ concentration is generally consistent across growth stages. Hodges and Baker (1993) found that, as cotton plants aged, the $\mathrm{NO}_{3}-\mathrm{N}$ concentrations measured in expressed petiole sap increased in proportion to that measured in dried petioles. They suggested that moisture content strongly affected the petiole sap measurement because it was more difficult to express the sap from older cotton plants. In contrast to cotton, cauliflower petioles become more succulent with age, resulting in easier sap expression. The moisture contents of the petioles averaged $92.0 \%$ in $1993-94$ and $91.8 \%$ in $1994-95$ by weight over all sampling dates and did not change significantly with plant age (data not shown).

Regression coefficients (slope and intercept) for data from the three irrigation treatments did not differ significantly $(P<0.05)$ within either season (Table 4). Therefore, the relationship between sap $\mathrm{NO}_{3}-\mathrm{N}$ and dried petiole $\mathrm{NO}_{3}-\mathrm{N}$ was not affected by differences in crop water status. Overall, these results suggest that using a single relationship between sap $\mathrm{NO}_{3}-\mathrm{N}$ and petiole $\mathrm{NO}_{3}-\mathrm{N}$ throughout cauliflower growth, irrespective of irrigation water management, is appropriate.

The $\mathrm{NO}_{3}-\mathrm{N}$ concentrations of cauliflower petiole sap, as measured by the Cardy meter, were highly correlated with dried petiole $\mathrm{NO}_{3}-\mathrm{N}$ in both years (Fig. 1). Each of the linear regression equations was significant at $P<0.01$. There were no significant differences $(P<0.05)$ between slopes of the regression equations from 1993-94 and 1994-95. Intercepts of the equations were slightly different $(P<0.01)$ between years. Although statistically different, the intercept values were numerically similar and had only a minor impact on estimated sap $\mathrm{NO}_{3}-\mathrm{N}$ values. Therefore, we combined the results from both years into a single linear regression equation. This combined equation is:

$\mathrm{Y}=0.047 \mathrm{X}+218\left(\mathrm{n}=341, \mathrm{r}^{2}=0.7723 * *\right)[1]$ where $\mathrm{Y}$ is $\mathrm{NO}_{3}-\mathrm{N}$ in petiole sap $\left(\mathrm{mg} \cdot \mathrm{L}^{-1}\right)$ and $\mathrm{X}$ is $\mathrm{NO}_{3}-\mathrm{N}$ in dried petiole tissue $\left(\mathrm{mg} \cdot \mathrm{kg}^{-1}\right)$. The standard errors of the slope and intercept

Table 3. Regression equations relating $\mathrm{NO}_{3}-\mathrm{N}$ concentration in cauliflower petiole sap (y) to dry tissue $\mathrm{NO}_{3}-\mathrm{N}(\mathrm{x})$ for several growth stages/sampling dates during the 1993-94 and 1994-95 growing seasons.

\begin{tabular}{|c|c|c|c|c|c|}
\hline \multicolumn{3}{|c|}{ 1993-94 } & \multicolumn{3}{|c|}{ 1994-95 } \\
\hline Growth stage & Date & Regression equation & Growth stage & Date & Regression equation \\
\hline 6- to 7-leaf & 21 Oct. & $y=0.043 x+177\left(n=16, r^{2}=0.876\right)$ & 5-leaf & 3 Nov. & $y=0.046 x+252\left(n=16, r^{2}=0.956\right)$ \\
\hline 8- to 10-leaf & 12 Nov. & $\mathrm{y}=0.035 \mathrm{x}+433\left(\mathrm{n}=47, \mathrm{r}^{2}=0.540\right)$ & 7- to 8-leaf & 17 Nov. & $y=0.046 x+266\left(n=56, r^{2}=0.660\right)$ \\
\hline Buttoning & 20 Dec. & $y=0.073 x+150\left(n=48, r^{2}=0.942\right)$ & Folding & 13 Dec. & $y=0.042 x+255\left(n=56, r^{2}=0.746\right)$ \\
\hline Harvest & 28 Jan. & $y=0.061 x+88\left(n=48, r^{2}=0.905\right)$ & Buttoning & 5 Jan. & $y=0.037 x+218\left(n=54, r^{2}=0.584\right)$ \\
\hline
\end{tabular}




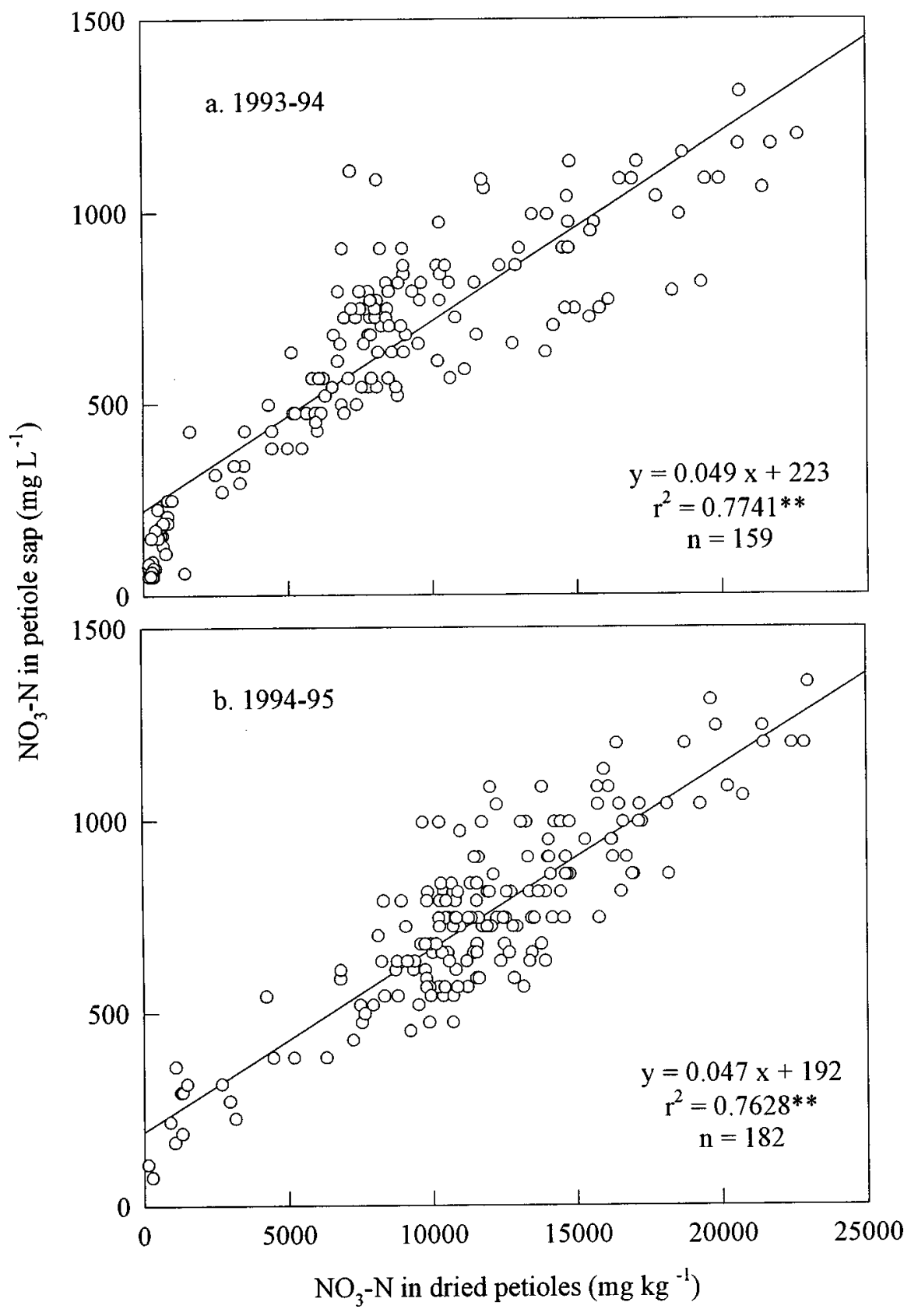

Fig. 1. Relationship between $\mathrm{NO}_{3}-\mathrm{N}$ concentration in cauliflower petiole sap measured by the Cardy meter and dried petiole $\mathrm{NO}_{3}-\mathrm{N}$ concentration measured by the nitrate-selective ion electrode during the (a) 1993-94 and (b) 1994-95 growing seasons.

Table 4. Regression equations relating $\mathrm{NO}_{3}-\mathrm{N}$ concentration in cauliflower petiole sap (y) to dry tissue $\mathrm{NO}_{3}-\mathrm{N}(\mathrm{x})$ for each irrigation treatment during the 1993-94 and 1994-95 growing seasons.

\begin{tabular}{lll}
\hline \hline $\begin{array}{l}\text { Irrigation } \\
\text { treatment }\end{array}$ & \multicolumn{1}{c}{$1993-94$} & $1994-95$ \\
\hline Deficient & $\mathrm{y}=0.051 \mathrm{x}+217\left(\mathrm{n}=47, \mathrm{r}^{2}=0.797\right)$ & $\mathrm{y}=0.049 \mathrm{x}+160\left(\mathrm{n}=48, \mathrm{r}^{2}=0.577\right)$ \\
Optimum & $\mathrm{y}=0.051 \mathrm{x}+213\left(\mathrm{n}=48, \mathrm{r}^{2}=0.775\right)$ & $\mathrm{y}=0.050 \mathrm{x}+152\left(\mathrm{n}=70, \mathrm{r}^{2}=0.776\right)$ \\
Excessive & $\mathrm{y}=0.062 \mathrm{x}+171\left(\mathrm{n}=48, \mathrm{r}^{2}=0.800\right)$ & $\mathrm{y}=0.038 \mathrm{x}+320\left(\mathrm{n}=48, \mathrm{r}^{2}=0.409\right)$ \\
\hline
\end{tabular}

were \pm 0.0014 and \pm 132 , respectively. This equation is based on the assumption that plants are taking up $\mathrm{N}$ mostly as $\mathrm{NO}_{3}^{-}$. In situations where cauliflower is taking up substantial amounts of $\mathrm{NH}_{4}^{+}$, this equation may not be appropriate. The quick sap test provides values that are well correlated with conventional dry tissue analysis. Our results agree with those of other scientists who observed high correlations for potato (Westcott et al., 1993) and for several other vegetable crops (Hartz et al., 1994).

To estimate whether the sap test and dried petiole analysis measured the same pool of petiole $\mathrm{NO}_{3}$, the $\mathrm{NO}_{3}-\mathrm{N}$ concentration of petiole sap was converted to a dry matter basis. We assumed that the density of the expressed petiole sap was equal to that of the moisture contained in fresh petiole samples. Nitrate-N concentrations on a dry matter basis, converted from the sap test measurement, were generally lower than those measured in dried petioles, as indicated by slopes <1 (Table 5). Prasad and Spiers (1984) compared sap $\mathrm{NO}_{3}-\mathrm{N}$ converted to a dry matter basis to dried petiole $\mathrm{NO}_{3}-\mathrm{N}$ for carrot (Daucus carota $\mathrm{L}$.), celery, potato, sweet corn, and tomato. The slopes varied from 0.8 to 1.8 , depending on the type of vegetable crop and growth stage. They suggested that lower sap $\mathrm{NO}_{3}-\mathrm{N}$ values compared to dried petiole $\mathrm{NO}_{3}-\mathrm{N}$ could be due to selective loss of dry matter as a result of drying. Losses of $\mathrm{C}$ and dry matter at 60C may occur by enzymatic or thermochemical degradation (Mayland, 1968). Westcott et al. (1993) explained that the difference between the two measurements may be due to interferences in the sap samples. The dried petiole analysis includes $\mathrm{Al}_{2}\left(\mathrm{SO}_{4}\right)_{3}$ in the extracting solution to reduce interferences, and the absence of $\mathrm{Al}_{2}\left(\mathrm{SO}_{4}\right)_{3}$ in the analysis of the sap samples may partly explain the differing results between the methods.

The difference between the two methods may also be partly due to the failure of the sap test to express some portion of tissue water. In the dry tissue analysis procedure, all free $\mathrm{NO}_{3}-\mathrm{N}$ in the petiole is extracted. However, in the sap test not all of the free $\mathrm{NO}_{3}-\mathrm{N}$ is expressed. Although these two methods may measure different quantities of $\mathrm{NO}_{3}-\mathrm{N}$ in petioles, the high correlations obtained suggest that the sap test for $\mathrm{NO}_{3}-\mathrm{N}$ can be used with existing tissue test recommendations for cauliflower.

These results suggest that Eq. [1] is applicable over a wide range of $\mathrm{N}$ and water status and, therefore, the quick sap test using the Cardy meter is a valuable technique to monitor $\mathrm{N}$ status of cauliflower. Equation [1] can be used to relate quick sap test measurements to

Table 5. Regression equations relating $\mathrm{NO}_{3}-\mathrm{N}$ concentration on a dry matter basis in cauliflower petiole tissue as analyzed by the Cardy meter (y) and the nitrateselective electrode (x) in $\mathrm{mg} \cdot \mathrm{kg}^{-1}$ for several growth stages/sampling dates during the 1993-94 and 1994-95 growing seasons.

\begin{tabular}{|c|c|c|c|c|c|}
\hline \multicolumn{3}{|r|}{$1993-94$} & \multicolumn{3}{|r|}{ 1994-95 } \\
\hline Growth stage & Date & Regression equation & Growth stage & Date & Regression equation \\
\hline 6- to 7-leaf & 21 Oct. & No moisture data & 5-leaf & 3 Nov. & $\mathrm{y}=0.645 \mathrm{x}+2635\left(\mathrm{n}=16, \mathrm{r}^{2}=0.964\right)$ \\
\hline 8- to 10-leaf & 12 Nov. & $y=0.430 x+3303\left(n=47, r^{2}=0.307\right)$ & 7- to 8-leaf & 17 Nov. & $y=0.591 x+1743\left(n=56, r^{2}=0.777\right)$ \\
\hline Buttoning & 20 Dec. & $\mathrm{y}=0.841 \mathrm{x}+1100\left(\mathrm{n}=48, \mathrm{r}^{2}=0.955\right)$ & Folding & 13 Dec. & $y=0.461 x+2321\left(n=56, r^{2}=0.732\right)$ \\
\hline Harvest & 28 Jan. & $\mathrm{y}=0.832 \mathrm{x}+630\left(\mathrm{n}=48, \mathrm{r}^{2}=0.870\right)$ & Buttoning & 5 Jan. & $y=0.510 x+2460\left(n=54, r^{2}=0.582\right)$ \\
\hline
\end{tabular}


Table 6. Desirable levels of $\mathrm{NO}_{3}-\mathrm{N}$, as measured by dry tissue analysis and the sap test in cauliflower petioles at various stages of growth.

\begin{tabular}{lcc}
\hline \hline & \multicolumn{2}{c}{$\begin{array}{c}\text { Desirable levels of petiole } \\
\mathrm{NO}_{3} \text {-N }\end{array}$} \\
\cline { 2 - 3 } Growth stage & $\begin{array}{c}\text { Dry tissue } \text { analysis }^{\mathrm{z}} \\
\left(\mathrm{mg}^{\mathrm{k}} \mathrm{kg}^{-1}\right)\end{array}$ & $\begin{array}{c}\text { Sap test } \\
\left(\mathrm{mg} \cdot \mathrm{L}^{-1}\right)\end{array}$ \\
\hline 4- to 6-leaf & 11,000 & 740 \\
10- to 12-leaf & 9,000 & 640 \\
Folding & 7,000 & 550 \\
Buttoning & 6,000 & 500 \\
Curd development & 2,500 & 340 \\
Preharvest & 1,500 & 290 \\
\hline
\end{tabular}

${ }^{\mathrm{z} F r o m ~ D o e r g e ~ e t ~ a l . ~(1991) . ~}$

${ }^{y}$ Converted by the combined regression equation (Eq. [1]).

existing guidelines for $\mathrm{NO}_{3}-\mathrm{N}$ concentrations in cauliflower petioles. Gardner and Roth (1990), and Doerge et al. (1991) suggested desirable levels of $\mathrm{NO}_{3}-\mathrm{N}$ in dried cauliflower petioles for various growth stages. These values have been converted to sap $\mathrm{NO}_{3}-\mathrm{N}$ concentrations using Eq. [1] (Table 6). These desirable levels of sap $\mathrm{NO}_{3}-\mathrm{N}$ in cauliflower petioles are applicable to conditions found in the desert regions of Arizona and possibly other arid and semi-arid regions. However, factors that may affect the sap test measurements under field conditions should be examined in future research.

\section{Literature Cited}

Baker, W.H. and T.L. Thompson. 1992. Determination of nitrate nitrogen in plant samples by selective ion electrode. Southern Coop. Bul. 368:25-28.

Beverly, R.B. 1994. Stem sap testing as a real-time guide to tomato seedling nitrogen and potassium fertilization. Commun. Soil Sci. Plant Anal. 25:1045-1056.

Doerge, T.A., R.L. Roth, and B.R. Gardner. 1991. Nitrogen fertilizer management in Arizona. Univ. of Arizona, College of Agriculture, Rpt. 191025.

Gardner, B.R. and R.L. Roth. 1990. Midrib nitrate concentration as a means for determining nitrogen needs of cauliflower. J. Plant Nutr. 13:14351451

Geraldson, C.M., G.R. Klacan, and O.A. Lorenz. 1973. Plant analysis as an aid in fertilizing vegetable crops, p. 365-379. In: L.M. Walsh and J.D. Beaton (eds.). Soil testing and plant analysis. Soil Sci. Soc. Amer. Madison, Wis.

Hartz, T.K., M. LeStrange, and D.M. May. 1993. Nitrogen requirements of drip irrigated peppers. HortScience 28:1097-1099.

Hartz, T.K., R.F. Smith, K.F. Schulbach, and M. LeStrange. 1994. On-farm nitrogen tests improve fertilizer efficiency, protect groundwater. Calif. Agr. 48(4):29-32.

Hochmuth, G. 1992. Plant sap testing for nitrogen, potassium. Citrus Veg. Mag. Feb.:55-56.

Hodges, S.C. and S. Baker. 1993. Correlation of plant sap extracts of nitrate- $\mathrm{N}$ and $\mathrm{K}$ with dried petiole extracts. Proc. Beltwide Cotton Conf. Natl. Cotton Council, Memphis, Tenn. p. 13351337.

Lorenz, O.A. 1965. Better vegetable yields and quality with plant analysis. Plant Food Rev. $11: 2-4$.

Mayland, H.F. 1968. Effect of drying methods on losses of carbon, nitrogen and dry matter from alfalfa. Agron. J. 60:658-659.

Papastylianou, I. 1989. Diagnosing nitrogen fertilization requirements of cereals in less than 30 seconds. Commun. Soil Sci. Plant Anal. 20:1247-1259.

Prasad, M. and T.M. Spiers. 1984. Evaluation of a rapid method for plant sap nitrate analysis. Commun. Soil Sci. Plant Anal. 15:673-679.

Scaife, A. and K.L. Stevens. 1983. Monitoring sap nitrate in vegetable crops: Comparison of test strips with electrode methods, and effects of time of day and leaf position. Commun. Soil Sci. Plant Anal. 14:761-771.

Sherman, W. and B. Erwin. 1995. 1994 Arizona agricultural statistics. Arizona Agr. Stat. Serv., Phoenix.

Snedecor, G.W. and W.G. Cochran. 1980. Comparison of regression lines, p. 385-388. In: Statistical methods. 7th ed. Iowa State Univ. Press, Ames.

Snyder, R.L. 1985. Hand calculating degree days. Agr. Forest Meterol. 35:353-358.

Welch, N.C., K.B. Tayler, D. Ririe, and F.E. Broadbent. 1985. Nitrogen uptake by cauliflower. Calif. Agr. 39(5-6):12-13.

Westcott, M.P., C.J. Rosen, and W.P. Inskeep. 1993. Direct measurement of petiole sap nitrate in potato to determine crop nitrogen status. J. Plant Nutr. 16:515-521.

Williams, C.M.J. and N.A. Maier. 1990. Determination of the nitrogen status of irrigated potato crops II. A simple on-farm quick test for nitratenitrogen in petiole sap. J. Plant Nutr. 13:985-993. 